\author{
Alicja STĘPNIEWSKA \\ (Lublin, KUL)
}

\title{
SĘDZIWI OJCOWIE - LAERTES I PRIAM W EPOPEJACH HOMERA
}

Problem starości w twórczości Homera był wielokrotnie poruszany w licznych opracowaniach ${ }^{1}$. Zofia Abramowiczówna zwróciła uwagę, że kiedy Homer mówi o starości charakteryzuje ją głównie za pomocą negatywnych

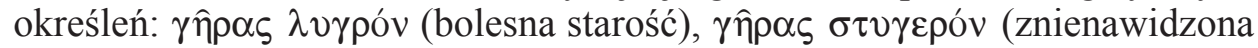

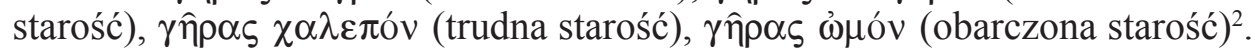
Zdawać by się więc mogło, że poeta nie łączył starości z jakimiś pozytywnymi wartościami, jak mądrość, doświadczenie, opanowanie czy przezorność. Tymczasem tego rodzaju zalety podeszłego wieku można odnaleźć u niektórych bohaterów jego poematów.

Najbardziej znaną postacią wśród długowiecznych był Nestor, władca Pylos, cieszący się ogromnym autorytetem, wymieniany przez Homera jako

${ }^{1}$ Por. Z. Abramowiczówna, Starość u Homera, „Meander” 37 (1982) 291-297; S. Byl, Lamentations sur la vieillesse chez Homère et les poètes lyriques des VII et VI siècles, „Les Etudes Classiques" 44 (1976) 234-244; J.N. Corvisier, La vieillesse en Grèce ancienne d'Homère à l'époque hellénistique, „Annales de Démographie Historique” 20 (1985) 53-70; T.M. Falkner, Epi geraos oydo. Homeric heroism, old age and the end of Odyssey, w: Old age in Greek and Latin literature, ed. T.M. Falkner - J. de Luce, Albany (NY) 1989, 21-67; M.J. Finley, The ederly in classical antiquity, „Greece and Rome” 28 (1981) 156-171; O. Fuà, La dignità dell'anziano negli scrittori greci fino al IV secolo a.C., „Atti dell'Istituto Veneto di Scienze. Lettere ed Arti” 138 (1979-1980) 397-414; W. Jungclaussen, Über das Greisenalter bei Homer, Flensburg 1970; G. Minois, Historia starości od antyku do renesansu, thum. K. Marczewska, Warszawa 1995, 54-57 (Rada starszych w Grecji homeryckiej); P. Ostański, Historiozbawcza wizja starości. Studium egzegetyczno-teologiczne, Poznań 2007, 168-169 (Homer); C.A. Ouerbach, Conflicts between young and old in Homer's Iliad, w: The conflict of generations in ancient Greece and Rome, ed. S. Bertman, Amsterdam 1976, 55-64; H. Podbielski, Starość i starcy w poematach Homera, w: Dojrzewanie do petni życia. Starość w literaturze polskiej i obcej, red. S. Kruk - E. Flis-Czerniak, Lublin 2006, 59-70; F. Preisshofen, Untersuchungen zur Darstellung des Greisenalters in der frühgriechischen Dichtung, Wiesbaden 1977; F. Schweingruber, Jugend und Alter in der griechischen Literatur von Homer bis Aristoteles, Diss., Zürich 1918; H.M. Stahmer, The Aged in two ancient oral cultures: the ancient Hebrews and Homeric Greece, w: Aging and ederly. Humanistic perspectives in gerontology, eds. S. Spiker - K. Woodward, Atlantic Higlands (NY) 1978, 23-36; P. Zucchelli, I poemi e gli inni omerici, w: Senectus. La vecchiaia nel mondo classico, ed. U. Mattioli, t. 1: Grecia, Bologna 1995, 1-58.

${ }^{2}$ Por. Abramowiczówna, Starość u Homera, s. 281; Ostański, Historiozbawcza wizja starości, s. 168. 
najbardziej doświadczony i najmądrzejszy z Achajów³. Do starców można jeszcze zaliczyć Priama - króla Troi, Laertesa - króla Itaki, a także niewidomego aojda Demodoka ${ }^{4}$ oraz wróżbitę Tejresjasza ${ }^{5}$. W obu eposach występuja również stare kobiety - Hekabe ${ }^{6}$, żona Priama i roztropna Eurykleja ${ }^{7}$, piastunka Odysa i Telemacha. Spośród postaci w podeszłym wieku występujących na kartach obu epopei przedstawię położenie dwóch starców - Laertesa, króla Itaki oraz Priama, króla Troi. Obaj czuli się ludźmi nieszczęśliwymi, których doświadczył podobny los, choć w różnym wymiarze. Syn Laertesa - Odys zaginął bez wieści, natomiast syn Priama - Hektor poniósł śmierć w pojedynku.

Na przykładzie Laertesa, jednego z bohaterów Odysei poeta ukazał, że starość człowieka majętnego, ogólnie szanowanego, mogła upływać spokojnie i szczęśliwie w rodzinnym gronie, gdyby nie ważne okoliczności, które w sposób radykalny zaważyły na życiu całej rodziny.

Jego bowiem syn Odys, aktualny król Itaki, powodowany poczuciem jedności z innymi Achajami za swój obowiązek uznał wzięcie udziału w wojnie trojańskiej. Tuż przed wyjazdem, żegnając się z żoną Penelopą, na czas swojej nieobecności, a zwłaszcza gdyby nie powrócił z wojny, powierzył jej, jak sama wspomina, pieczę nad całym domem, a także otoczenie szczególną troską starych rodziców - ojca Laertesa i matkę Antikleję oraz synka Telemacha. Jednocześnie dał jej wskazówki na przyszłość:

„Nie wszyscy ci pancerni męże, droga żono,

Którzy idą na Ilion, powrócą tu pono.

Bo i Trojańcy w boju dzielnie, jak słyszałem,

Robią kopią, miotają z łuków celnym strzałem,

Toż lotnym toczą koniem, a dziarskie to zwierzę

Zwykło dawać zwycięstwo w chwiejnym bitwy wirze.

Przeto nie wiem, czy bóg mię stamtąd przyprowadzi,

Czy tam liszy? Więc głowa twoja niech tu radzi:

$\mathrm{W}$ domu miejże o ojcu, o matce staranie

${ }^{3}$ Por. Homerus, Ilias I 247; II 76-77, 336-368, 432-440, 591-592; IV 293-294; VII 123-124, 170-171, 323-324; VIII 80-159; IX 52-53, 92-93, 162-181; X 73-176, 180-271, 531-553; XI 516-520, 618-642, 645-804; XV 367-378, 659-660; XXIII 304-305, 615-652; Odyssea II 16; III 165-166, 452-453; XXIV 52; E. Reychman-Lee, Nestor i inni. Przykłady dlugowieczności wśród starożytnych, „Meander” 37 (1982) 317-323; RE XVII/1 108-123; P. Grimal, Stownik mitologii greckiej i rzymskiej, przekład zbiorowy, wyd. 3, Wrocław 1997, 250-251.

${ }^{4}$ Demodok, por. Homerus, Odyssea VIII 44-45; XIII 27; RE IV/2 2869-2870; Grimal s. 72.

${ }^{5}$ Tejresjasz, por. Homerus, Odyssea X 487-488; XI 84-85; XXIII 323; Grimal s. 337.

${ }^{6}$ Hekabe, por. Homerus, Ilias VI 293-294; XVI 718; XXII 82-83, 405-406, 430-431; XXIV 200-201, 286-287, 746-747; RE VII/2 2652-2662; Grimal s. 120-121.

${ }^{7}$ Eurykleja, por. Homerus, Odyssea I 429; XIX 401; RE VI/1 1328. 
Jak dotąd, a tym więcej, jeśli mnie nie stanie.

Gdy zaś syn nasz dojrzeje, wyjdzie na człowieka, Idź za mąż - twoja nad nim skończy się opieka"s.

Jak potoczyły się dalsze losy rodziców, Odys dowiaduje się dopiero po wielu latach tułaczki, kiedy schodzi do Hadesu. Tam, ku wielkiemu zaskoczeniu, wśród cieni rozpoznaje swoją matkę. Między obojgiem odbywa się wzruszający dialog. Odys pełen niepokoju zwraca się do matki prosząc ją o informacje:

„Lecz mów mi szczerą prawdę, o matko kochana!

W jakiż sposób napadła cię śmierć nieprzespana?

Zjadła-ż ciebie choroba? Czy łucznica ona,

Artemis, lekką strzałę wbiła ci do łona?

Mów o ojcu, o synu moim, co zostali:

Czy godność moją dzierżą, czyli też ją zdali

Komu z mężów, zwątpiwszy, czy żyję na świecie?

Powiedz, co tam małżonka moja myśli przecie?

Siedzi-ż jeszcze przy synu i z nim gospodarzy?

Czy poszła za którego z achajskich mocarzy?"’.

Obraz, który mu przedstawia, jest bardzo przygnębiający. Ojciec bowiem opuścił zamek zamieszkując na wsi, gdzie dogląda sadu i winnic. Żyje w ubóstwie, osamotnieniu i opuszczeniu. Chodzi zaniedbany, w łachmanach, w zimie śpi w izbie na ziemi przy ognisku razem ze służbą, natomiast latem i jesienią pod gołym niebem w winnicy na posłaniu z zeschłych liści. Długie bezsenne noce, jak wspomina matka, upływają mu na rozmyślaniach nad niedolą syna. Bezsilność i postępująca starość stają się dla ojca coraz bardziej uciążliwe, a ból do głębi przeszywa jego serce $\mathrm{z}$ tęsknoty za, być może, utraconym na zawsze synem:

„Rodzic twój na łanie

Osiadł sobie i w mieście nigdy nie postanie.

Łoże jego nie świeci makatą tam żadną

Ni chlajnami; na zimę ma izbę czeladną,

W której sypia; zazwyczaj na ziemi w popiele

Kładnie się przy ognisku i łachman podściele;

W łagodniejsze zaś lato i jesień owocną

Rad chodzi po winnicach sypiać porą nocną,

Kędy sobie ze suchych liści łoże mości.

A nim zaśnie, wciąż duma o losów srogości

Sprzysiężonych na ciebie, i w serce się wpija

Nowy ból, a lat ciężar do reszty zabija" ${ }^{10}$.

${ }^{8}$ Homerus, Odyssea XVIII 265-276, thum. L. Siemieński: Homer, Odyseja, BN II 21, Wrocław 2003, 381-382. Z tego wydania będą pochodziły dalsze cytaty z Odysei.

${ }^{9}$ Tamże XI 173-182, tłum. Siemieński, s. 230-231.

${ }^{10}$ Tamże XI 191-203, tłum. Siemieński, s. 231. 
Matka natomiast odpowiadając Odysowi na nurtujące go pytania dotyczące jej śmierci wyjawia, że to nie ciężka choroba, ani strzała Artemidy pozbawily ją życia, lecz ciagła tęsknota za nim, która opanowała całe jej jestestwo doprowadzając w konsekwencji do śmierci. Fakt ten bardzo poruszył i rozczulił Odysa. Trudno mu było rozstać się z matką nie mogąc jej nawet wziąć w ramiona. Na pożegnanie matka ubolewając nad tułaczym życiem Odysa z tkliwością wypowiada znamienne słowa: „Synu! Najnieszczęśliwszy z ludzi na tej ziemi!” Jednocześnie mobilizuje go do jak najszybszego wyjścia z Hadesu i powrotu do świata żywych - tam gdzie jego miejsce, gdzie oczekują go najbliżsi - wierna żona Penelopa, syn Telemach i stary ojciec. Te pokrzepiające słowa matki, że ma gdzie i do kogo wrócić, podbudowały Odysa i wpłynęły na decyzję szybkiego powrotu do Itaki. Scena ta stanowi jakby pierwsze ogniwo ciagu informacji. Uświadamia Odysowi prawdę o faktycznym życiu starych rodziców.

Drugie ogniwo - to spotkanie Odysa w przebraniu żebraka z pasterzem Eumajosem. Dzięki zatajeniu własnej tożsamości Odys otrzymuje od pasterza szczerą odpowiedź:

„Z ust mych prawdę usłyszysz, wszystko będziesz wiedział

Laertes dotąd żyje, choć boga wciąż prosi,

By śmierć zesłał na niego; życia już nie znosi,

Odkąd utrata syna serce mu rozdarła

I odkąd mu małżonka, cna pani, umarła.

Z płaczu przyszła nań starość wczesna i przygniata;

Ona także z tęsknoty po synie ze świata

Zeszła śmiercią okropną. O! Niech tak nie kończy

Nikt dobry, kto mię kocha, z kim przyjaźń mię łączy!

Dopóki ona żyła, choć smutkiem przybita,

Dopóty wszystkim dla mnie była ta kobieta" $"$.

Stopniowo więc rozszerza się i wzbogaca o nowe treści zakres wiadomości o starym ojcu i matce. Życie Laertesa po śmierci żony, jak mówi Eumajos, stało się nie do zniesienia. Dotąd bowiem wspólnie dzielili smutki i troski wzajemnie się wspierając, a po jej odejściu zapanowała całkowita pustka. Rozpacz, która go ogarnęła, przyspieszyła jeszcze proces starzenia. Brak syna i żony - to cios nie do udźwignięcia, dlatego modli się ciągle do boga prosząc o rychłą śmierć, nie widząc sensu dalszego życia.

$\mathrm{Z}$ wielkim szacunkiem wypowiada się o zmarłej matce Odysa - Antiklei. Długotrwała i pogłębiająca się tęsknota za synem oraz postępujące lata życia doprowadziły ją w końcu do śmierci, a takiej śmierci, jak zaznacza, nie życzy nikomu, kto okazał mu życzliwość i zrozumienie. Mimo smutku potrafiła jednak nieść pociechę innym. On sam zaznał od niej wiele ciepła. Była dla niego jak matka. Mógł z nią porozmawiać, powierzyć jej swoje troski i wypłakać się.

${ }^{11}$ Tamże XV 352-362, thum. Siemieński, s. 322. 
Odysowi pozostało jeszcze ważne spotkanie, spotkanie niełatwe, związane bowiem z przeżyciem ujrzenia ojca po dwudziestu latach rozłąki i jednocześnie przeprowadzeniem z nim rozmowy w taki sposób, by nie spowodować nadmiernego wstrząsu psychicznego u starca. Dotychczas o ciężkim życiu Laertesa Odys dowiedział się z dwóch źródeł - od matki i Eumajosa, obecnie przekona się naocznie, jak wyglądała smutna rzeczywistość. Będzie to ostatnie ogniwo zamykające ciag informacji, teraz jednak uzyskanych w sposób bezpośredni - z osobistej obserwacji i rozmowy z ojcem.

W sadzie, dokąd się udał, zobaczył przygarbionego ojca okopującego drzewko. Widok był przygniatający. Przystanął pod gruszą i gorzko zapłakał nad losem i starością bliskiego mu człowieka. Ojciec był zaniedbany, miał na sobie brudny, połatany stary chiton, golenie obwiązane skórą wołowa, na dłoniach rękawice z kawałków skóry, głowę okrywała czapka z koźlej skóry. Odys widząc ojca w stanie żałoby rozważał, jak postapić: czy od razu powiedzieć, kim jest, czy ukryć chwilowo swą tożsamość przygotowując go stopniowo do wyjawienia prawdy. Wybrał drugie wyjście, zwracając się do ojca:

„Starcze! Z ciebie ogrodnik, widzę, wyśmienity,

Wszędzie znać pilną rękę w uprawie tych sadów,

Tak koło fig, oliwek, grusz, jak winogradów.

Każdy szczep, każda grządka uprawna jak rzadko,

Jedno tylko zarzucę - przebaczy mi tatko! -

Że sam nie dbasz o siebie. Starzec, wiekiem zgięty,

Chodzi taki obdarty i nieogarnięty!

Pewnie nie za lenistwo pan o cię nie stoi -

Nie widać niewolnika przecież z twarzy twojej,

Owszem, coś królewskiego masz w całej postawie,

Ni to pan co po łaźni i wytwornej strawie

Zażywa lekkiej drzemki, jak u starych zwyczaj.

Przeto mów mi, kto jesteś, z prawdą się nie sprzeczaj.

Kto cię trzyma parobkiem do pracy w ogrodzie?

Opowiedz to dokładnie, niech wiem w mej przygodzie,

Czy na wyspie Itace naprawdę stanąłem"12.

Dalej snuł opowieść o rzekomym spotkaniu z Odysem wracającym do Itaki, którego gościł u siebie i obdarował, a także o wzajemnym zapewnieniu, że jeszcze nieraz się spotkają. Wspomnienie o synu bardzo poruszyło Laertesa, który szlochając rzekł:

„Przechodniu! Na Itace jesteś w rzeczy samej,

Gdzie pod władzą zuchwałych mężów tu stękamy.

${ }^{12}$ Tamże XXIV 250-265, thum. Siemieński, s. 490-491. 
Na próżno go szczodrymi dary obsypałeś.

O, czemuż go w Itace żywym nie zastałeś!’’13

Kiedy jednak starzec podniósł z ziemi garść popiołu i posypał siwą głowę zalewając się łzami z tęsknoty za utraconym synem, wówczas Odys do głębi wzruszony nie mogąc dłużej patrzeć na ból ojca, objął go i zaczął całować, wyznając jednocześnie kim jest:

„«Ojcze! Jam to jest syn twój - mówił - syn zgubiony,

Który wraca po latach dwudziestu w te strony!

A więc łzom tym pofolguj, nie wzdychaj już więcej!

Krótko powiem, gdyż działać trzeba nam co prędzej,

Żem wszystkie zalotniki w pień wyciął w mym domu:

Nie uszli ci zuchwalce mściwego pogromu!»

Odpowiedział mu na to ojciec, Laert stary:

«Żeby mój Odys wrócił, rzecz trudna do wiary;

Pokaż znamię, a wtedy zaufam twej mowie» ${ }^{14}$.

$\mathrm{Na}$ to mu bystromyślny Odysej odpowie:

«Ojcze mój! na tę bliznę nasamprzód zwróć oko,

Którą odyniec kłami rozorał głęboko»" "15.

„«Teraz wskażę ci wszystkie drzewa i krzewiny,

Darowane mi niegdyś, gdym jeszcze dziecięciem

Za tobą wbiegł w te sady i słuchał z zajęciem,

Jak każde drzewo mianem nazywałeś innym»"16.

Laertes omdlał z wrażenia i ze szczęścia. Powrót ukochanego syna przywrócił mu chęć do życia, a także zdopingował do walki, kiedy zaistniała konieczność ratowania domu Odysa przed grabieżcami. Ubrany w piękne szaty, godne królewskiego rodu, z nowymi siłami, którymi obdarzyła go hojnie bogini Atena walczył przy boku Odysa i wnuka Telemacha. Za pomyślny przebieg wypadków swą wdzięczność wyraził bogom:

„Bogowie! Dzień dzisiejszy dni moich ozdobą:

Syn z wnukiem o cześć przodków w zawód idą z sobą!"17.

${ }^{13}$ Tamże XXIV 287-290, tłum. Siemieński, s. 491.

${ }^{14} \mathrm{~W}$ scenie tej obserwujemy rozpoznanie syna Odysa przez ojca ze znaków - znamienia i blizny, po wcześniejszym samoujawnieniu się Odysa przed ojcem. W Odysei zresztą występuje seria rozpoznań (anagno-rismós), na których opiera się zasadniczo cały utwór. Odys bowiem rozpoznany zostaje, m.in. przez Alkinoosa, Telemacha, Eurykleję, Eumajosa, psa Argosa i na końcu - ojca Laertesa. Taką strukturę poematu opartą na licznych rozpoznaniach wykorzystał również A. Mickiewicz tworząc Pana Tadeusza (szerzej na ten temat zob. A. Stępniewska, Mickiewicz w kręgu Homera. Struktura epicka „Pana Tadeusza”, Lublin 1998).

${ }^{15}$ Homerus, Odyssea XXIV 329-340, tłum. Siemieński, s. 493.

${ }^{16}$ Tamże XXIV 344-347, tłum. Siemieński, s. 493-494.

${ }^{17}$ Tamże XXIV 527-528, tłum. Siemieński, s. 500. 
Laertes może być już spokojny o właściwe, stabilne zarządzanie majątkiem królewskim i zachowanie ciagłości rodu. Powrót syna jest bowiem gwarancją kontynuacji dziedziczenia władzy królewskiej, którą w przyszłości z pewnością przejmie jego wnuk Telemach. Dla starego Laertesa - to największa nagroda za dwadzieścia lat upokorzeń, niepokoju i oczekiwania.

Należy zwrócić uwagę, że Homer ukazując życie Laertesa w starości, posłużył się trzema relacjami, w których motywem dominującym była tęsknota za synem. Jedynym ratunkiem dla starca była ciężka praca w ogrodzie, która pochłaniała go całkowicie. Dbał z wielką pieczołowitością o każdy krzew winny i każde drzewko. Poeta chciał tu, być może, zaakcentować, że to właśnie w pracy można znaleźć chwilowe zapomnienie i ulgę w cierpieniu. Innym ważnym aspektem podkreślanym przez Homera jest również oparcie w rodzinie i zrozumienie wśród najbliższych. Fakt powrotu syna potrafił od razu zmienić perspektywy dalszego życia, dając poczucie bezpieczeństwa bezradnemu i zrezygnowanemu Laertesowi, który odzyskuje szacunek i należne mu miejsce w królestwie.

II.

Sytuacja starego Priama - króla Troi, bohatera Iliady, była bardziej skomplikowana. Przed murami Troi w pojedynku z Achillesem ginie najstarszy jego syn - Hektor, któremu ojciec ze względu na swój wiek powierzył władzę nad miastem i dowodzenie wojskami trojańskimi podczas trwającej wojny.

Achilles dumny i butny ze swego zwycięstwa posunął się do znieważenia zwłok Hektora, pomimo prośby umierającego, by za okup wydał jego ciało staremu ojcu. Obojętny na te słowa zdarł z trupa zbroję, przywiązał do rydwanu i wlekąc go w kurzu ruszył do obozu. Na to okrutne bezczeszczenie zwłok syna patrzyli z murów Troi zrozpaczeni rodzice - Priam i Hekabe oraz tłum trojańczyków:

„,... Matka nieszczęsna,

Widząc to, włosy rwie siwe, odrzuca lśniącą zasłonę

Precz poza siebie, z lamentem straszliwym patrzy na syna.

Jęczy żałośnie i ojciec kochany, a lud wkoło niego

Skargą wybucha i słychać po całym mieście szlochanie.

Najpodobniejsze to było do klęski - jakby już teraz

Ilion górzyste płonęło $\mathrm{w}$ ogniach niszczącej pożogi.

$\mathrm{Z}$ trudem ogromnym powstrzymał lud starca zrozpaczonego,

Co się wyrywał z rąk thumu, chcąc za Dardańskie wyjść bramy.

Błagał w krąg wszystkich, po brudnej, zmierzwionej tarzając się ziemi,

I po imieniu każdego z mężów wzywając, tak wołał:

„Puśćcie mnie, moi kochani, samego, nie troszczcie się o mnie,

Z miasta wyruszę i dotrę aż pod okręty Achajów,

Będę go błagał, zbrodniarza owego i okrutnika, 
Może mój wiek uszanuje podeszły, starcowi okaże

Litość. On przecież ma ojca też starca - podobny mi wiekiem -

Peleus. On dał mu życie i wyhodował na zgubę

Trojan, a dla mnie na boleść, ze wszystkich ludzkich największą

Bo pozabijał mi tylu dorodnych synów, kwitnących.

Wszystkich mi szkoda, lecz nie tak innych, jak tego jednego,

Żal po nim nieutulony aż do Hadesu mnie wpędzi,

Po mym Hektorze"18.

Homer opisał w tej scenie w sposób wyjątkowo sugestywny i naturalny reakcje starych rodziców w chwilę śmierci ukochanego syna Hektora. Szloch matki i jęk ojca udzieliły się natychmiast wszystkim zgromadzonym na murach i wkrótce lament ogarnął cały Ilion. Priam nie mogąc zapanować nad cierpieniem, w swej bezsilności, tarzając się po ziemi, błagał wszystkich dookoła, by wypuścili go poza mury miasta. Sam bowiem chciał udać się do Achillesa z nadzieją, że ulituje się on nad jego starością i odda mu zwłoki syna. Ta nagła, nieprzemyślana decyzja starego ojca, podjęta w momencie silnego napięcia, została z trudem udaremniona przez współczujący mu lud ${ }^{19}$. Księga ostatnia Iliady ukazuje dom Priama w stanie żałoby, gdzie zapanowała napięta sytuacja potęgowana jeszcze przez niepokój i bezradność, jak odzyskać zwłoki Hektora:

„...Tam płacz był i narzekanie.

Wkoło przy ojcu synowie wewnątrz dziedzińca siedzieli,

Łzami zraszając swe szaty. Nieszczęsny starzec pośrodku,

Chlajną okryty, na ziemi leżał, a mierzwa i błoto

Głowę starcowi sędziwą i całą szyję okryły,

Które, tarzając się w pyle, własnymi rękami nagarniał.

W domu zaś córki Pryjama wraz z synowymi płakały"20.

Ten niepokój rozwiewa Iris, posłanka Dzeusa, przynosząca pomyślną wiadomość od boga olimpijskiego, który nakazał Priamowi:

„Niech pod okręty Achajów pośpieszy syna wykupić,

Wziąwszy podarki bogate, by zjednać serce Achilla.

W drogę sam niechaj wyruszy, nie biorąc z Trojan nikogo,

Tylko starego herolda wolno mu wziąć, by prowadził

Muły i i wozem kierował o pięknych kołach, gdy wracać

Będą do miasta z poległym, którego zabił Achilles.

${ }^{18}$ Homerus, Ilias XXII 405-426, thum. K. Jeżewska: Homer, Iliada, BN II 17, Wrocław 1972, 460. Z tego wydania będą pochodziły dalsze cytaty z Iliady.

${ }^{19}$ H. Podbielski (Starość i starcy w poematach Homera, s. 68) o scenie tej napisał: „Trudno bowiem byłoby znaleźć w całej literaturze bardziej poruszającą swym szczerym patosem scenę niż scena rozpaczy dwojga starych rodziców, Priama i Hekabe, po śmierci Hektora, którego ciało na ich oczach bezcześci Achilles".

${ }^{20}$ Ilias XXIV 160-166, thum. Jeżewska, s. 499. 
Niechaj nie myśli o śmierci ni w sercu lęku nie chowa,

Bo przewodnika Hermesa za towarzysza mu dodam,

Który go będzie prowadził aż do samego Achilla.

A gdy go już do namiotu Achillowego przywiedzie,

Ten ni go sam nie zabije, ni innym na to pozwoli.

Taki zuchwały wszak nie jest, zawzięty ani bezbożny,

By nie oszczędzić człowieka, co przyszedł błagać litości”21.

Słowa Iris podbudowały starca i spowodowały otrząśnięcie się z przygnębienia pobudzając go do szybkiego działania. Mimo bólu, który tłumił w sercu, a także sędziwego wieku, wykazał odpowiedzialność oraz stanowczość, godną króla i ojca. Poczynił konieczne przygotowania, by móc jak najprędzej wyruszyć po zwłoki Hektora. Synom polecił zaprzegać muły, a sam osobiście zajął się wyborem wielu cennych darów, wśród których największym skarbem był puchar otrzymany od Traków, kiedy przybył do nich jako poseł. Nie żałował tego wyjątkowego daru, gdyż z całej duszy pragnął wykupić syna. Trwał mocno w swoim postanowieniu nie ulegając wstrzymującej go Hekabe:

„Biada! gdzie twoja rozwaga przepadła? Z której tak niegdyś

Pośród własnego narodu i obcych ludzi słynąłeś?

Chcesz ku okrętom Achajów sam, bez nikogo, wyruszyć,

Stanąć przed wzrokiem człowieka, co licznych i tak szlachetnych

Synów ci zabił? Zaiste, żelazne jest w tobie serce!

Jeśli on ciebie pochwyci, na własne oczy zobaczy -

Zdrajca, okrutnik - na pewno ci nie okaże litości

Ani szacunku"22.

O zmierzchu, w towarzystwie herolda, Priam wyruszył do obozu Achillesa, szczęśliwie docierając do namiotu. Herolda pozostawił na zewnątrz przy mułach i koniach, a sam wszedł niepostrzeżony do środka. Zbliżywszy się do zabójcy syna objął jego kolana i całując mu ręce rzekł błagalnym głosem:

„«Wspomnij na ojca swojego, do bogów podobny Achillu.

W moich on latach jest teraz i stoi na progu starości.

Może go jacyś sąsiedzi zamieszkujący wokoło

Dręcza, a nikt go od zguby i od napaści nie broni.

Ale i on gdy o tobie, że jeszcze żyjesz, usłyszy,

Radość ma w sercu i potem każdego dnia się spodziewa

Syna miłego zobaczyć wracającego spod Troi.

Mnie już pocieszyć nie zdoła nic, bo z mych synów walecznych

W Troi rozległej zrodzonych - żaden mi już nie pozostał.

Pięćdziesięciu ich było, gdy przyszli synowie Achajów;

\footnotetext{
${ }^{21}$ Tamże XXIV 146-158, tłum. Jeżewska, s. 498-499.

${ }^{22}$ Tamże XXIV 201-208, tłum. Jeżewska, s. 500.
} 
Z nich dziewiętnastu małżonki jednej zrodziło mi łono,

Resztę na świat mi wydały kobiety w pałacu żyjące.

Wielu z mych synów gwałtowny Ares rozwiązał kolana.

Jeden, co z wszystkich mi został, osłaniał miasto i Trojan -

Ty go niedawno zabiłeś, Hektora, gdy swojej ojczyzny

Bronił. Dla niego przybyłem dziś pod okręty Achajów,

Aby wyzwolić go, okup przynosząc ci niezmierzony.

Bogów uszanuj, Achillu, i miejże litość nade mną,

Wspomnij o ojcu swym własnym. Jam jest godniejszy litości -

Nikt ze śmiertelnych nie doznał tego, co ja dziś doznaję,

Kiedy do ust swych podnoszę rękę zabójcy mych dzieci».

Rzekł tak - i ojca wspomnieniem w Achillu żałość obudził.

Wziął rękę starca swą dłonią, odsunął lekko od siebie.

Obu wspomnienia objęły. Ten - przypominał Hektora,

Wrogów pogromcę - i płakał u nóg boskiego Achilla.

Tamten o ojcu rozmyślał i utraconym Patroklu,

Łzy wylewając. Ich głośne szlochania dom napełniły.

W końcu, gdy smutek bolesny wypłakał boski Achilles,

Kiedy już w sercu zmęczonym uciszył lament i skargi,

powstał i starca Pryjama dźwignął za ręce z podłogi -

Głowa go siwa i broda zbielała do głębi wzruszyły"23.

Priam z obawy przed nieprzewidzianą reakcją ze strony zaskoczonego Achillesa od razu starał się wywołać w nim wzruszenie przez przywołanie w pamięci obrazu jego ojca Peleusa, który, jak mówił, „stoi na progu starości”, podobnie jak on sam. Być może, dokucza mu samotność, źle obchodzą się z nim sąsiedzi i nie ma nikogo, kto udzieliłby mu wsparcia w niedoli. Przynajmniej jednak ma nadzieję, że syn żyje i któregoś dnia powróci spod Troi i właśnie to przeświadczenie pozwala mu wytrwać w oczekiwaniu na spotkanie z synem. Priam wie, jak wygląda starość, której sam zresztą doświadcza, dlatego potrafi wczuć się w położenie ojca Achillesa. Porównując jednak własny los do jego sytuacji stwierdził, że to on właśnie, Priam, godzien jest większej litości „kiedy do ust swych podnosi rękę zabójcy". Utracił ukochanego syna, który był jego ostoją w trudnych chwilach i obrońcą swojej ojczyzny. Prosi Achillesa, aby miał litość nad nim przez wzgląd na swego ojca. Wspomnienie o ojcu i tęsknota za nim stopniowo skruszyły gniew Achillesa pobudzając go do łez. Lekko odsunął od siebie rękę Priama i wspólnie szlochając oddali się wspomnieniom - jeden o dzielnym synu, drugi o ojcu i Patroklosie. Łzy, które były wyrazem głębokiego wzruszenia miały niejako moc oczyszczającą (kátharsis). Obaj doznali wewnętrznego wyciszenia i ukojenia. Kiedy Achilles opanował swój ból podniósł Priama za rękę z podłogi i rzekł do niego:

${ }^{23}$ Tamże XXIV 486-516, tłum. Jeżewska, s. 509-510. 
„Starcze nieszczęsny! Twe serce straszliwe ciosy przeżyło.

Jakże ty miałeś odwagę przyjść pod okręty Achajów,

Aby tu stać oko w oko z tym, co tak licznych i dzielnych

Synów ci zabił. Zaprawdę, żelazne jest w tobie serce"24.

Słowa Achillesa były wyrazem szczerego współczucia i zrozumienia dla starca, któremu los nie szczędził wielu nieszczęść, a także uznania dla jego odwagi, jaką wykazał przychodząc do obozu Achajów i zabójcy synów. Tak postąpić mógł tylko człowiek o nieugiętym sercu.

Autor Iliady w scenie spotkania Priam - Achilles ukazał, jak ważna jest trafna argumentacja, aby osiągnąć zamierzony cel. Przemyślany wcześniej sposób rozmowy przez starego, doświadczonego Priama i wysunięte przez niego racje przyniosły pozytywny skutek. Poruszenie bowiem czułej struny, dotyczącej starości osamotnionego Peleusa, spowodowało łatwiejsze dotarcie do serca Achillesa i doprowadziło w pewnym stopniu do jego wewnętrznej przemiany. Zawzięty, nieprzejednany wojownik powoli łagodnieje, wzrusza się i płacze na myśl o swoim ojcu, aż w końcu ubolewa nad nieszczęsnym losem Priama. Homer podkreślił również godną uwagi delikatność i szacunek w postawie Achillesa, który nie chcąc ranić uczuć zbolałego ojca i oszczędzić mu przykrego widoku sponiewieranych i poranionych zwłok syna kazał wcześniej służebnym, z dala od namiotu, obmyć potajemnie ciało, namaścić i owinąć w tkaniny i chlajnę pozostawionymi na wozie z jego polecenia, kiedy przenoszono okup, a następnie sam podniósł zwłoki i złożył na marach.

Achilles czuł się odpowiedzialny za bezpieczeństwo Priama, który był osobą nie tylko błagającą o litość, ale również jego gościem. ${ }^{25} \mathrm{~W}$ świecie homeryckim bowiem gościnność była ważnym elementem codziennego życia. Po wspólnej wieczerzy, aby nie dopuścić do rozpoznania przez Achajów w starcu - króla Troi, Achilles polecił służbie przygotować posłanie dla Priama i herolda poza namiotem. Okazując jeszcze swoją wyrozumiałość zwrócił się do starca:

„«Jeszcze mi na to odpowiedz - a śmiało, bez żadnej obawy -

Ile byś dni potrzebował na pogrzeb boskiego Hektora?

Mógłbym sam pokój zachować i wojsko powstrzymać od walki».

$\mathrm{Na}$ to do bogów podobny Pryjam sędziwy powiedział:

«Gdybyś pozwolił, bym uczcił pogrzebem boskiego Hektora,

Czynem tym mógłbyś, Achillu, najbardziej mnie uradować.

Miasto, jak o tym wiesz dobrze, jest oblężone, a lasy

Mamy daleko, aż w górach - tam boją się jeździć Trojanie.

Chciałbym mieć dziewięć dni w domu na opłakanie Hektora,

Dnia dziesiątego lud cały ognisty mu stos zapali,

W dniu jedenastym do grobu złożymy jego popioły.

${ }^{24}$ Tamże XXIV 518-521, tłum. Jeżewska, s. 510.

${ }^{25}$ Por. H. Wójtowicz, Gościnność u Homera, w: Księga pamiatkowa poświęcona prof. Zofii Abramowiczównie, red. W. Wróblewski, Toruń 1987, 127-139. 
Potem - gdy los tak nakaże - staniemy znowu do walki».

Na to mu tak odpowiedział o szybkich nogach Achilles:

«Niechże tak będzie, jak pragniesz, starcze sędziwy, Pryjamie!

Wojsko od walki powstrzymam tak długo, jak o to prosiłeś»».

Tak powiedział - i ujął starca za rękę w przegubie

Dłonią swą prawą, by resztę trwogi mu z serca wypłoszyć"26.

Homer, jak widać, zadbał o każdy szczegół, by nic dodatkowo nie zmąciło pobytu starca w obozie Achajów i pozwoliło mu szczęśliwie powrócić do domu z ciałem Hektora i gwarancją zawieszenia działań wojennych na okres pogrzebu. Priam o świcie wyruszył do Troi - nieszczęśliwy, że stracił syna, lecz zadowolony, że odzyskał jego zwłoki, by móc je godnie pochować.

Należy jeszcze podkreślić, że bohaterowie Homera to ludzie naturalni mający pozytywne i negatywne reakcje, pełni życia, którzy ucieleśniają różne cechy charakteru, takie jak odwaga, bojaźń, szlachetność, łagodność, zaciętość, chwiejność, wielkoduszność, a także uzewnętrzniają bogatą sferę uczuć - miłość, nienawiść, przyjaźń, wrogość, radość, smutek, tęsknotę, gniew, rozpacz, wdzięczność.

Ponad 25 wieków później Adam Mickiewicz w wykładach z Literatury słowiańskiej, prowadzonych w latach 1840-1844 w Collège de France w Paryżu, wykazując wpływ eposu greckiego na słowiańską twórczość epicką, stwierdził, ,że po upływie tylu wieków nikt spośród poetów nie zbliżył się nawet do Homera $\mathrm{w}$ znajomości wielkich tajników człowieczeństwa" ${ }^{27}$. Słowa te - to najwyższy hołd złożony greckiemu poecie przez poetę polskiego.

\section{OLD FATHERS - LAERTES AND PRIAM IN EPICS OF HOMER}

\section{(Summary)}

Subject of the article are experience and sufferings two fathers - Laertes, King of Ithaca and Priam, King of Troy. They both had that experience in its old age, but in different dimension. Son of the first of fathers - Odys has disappeared without tidings, but he came back to Ithaca after twenty years of wandering, to the great joy of longing father. The son of the second of fathers - Hector was killed in a duel with Achilles. The aged Priam in difficult conversation with his son's killer is reminding Achilles the suffering of his aged father Peleus, who is living in loneliness, to break heart of Achilles. Due to well-aimed arguments, particularly adduction for the feckless old age of the father, aged Priam reaches intentional point - gets corpse of his son back.

${ }^{26}$ Ilias XXIV 655-671, tłum. Jeżewska, s. 514-515.

${ }^{27}$ A. Mickiewicz, Literatura słowiańska, Kurs trzeci, wykład XVI, w: Dzieła, wydanie rocznicowe 1798-1998, t. 10, Warszawa 1998, 201. 